\title{
norden
}

Nordiska rådet

Ved Stranden 18

DK-1061 København K

www.norden.org

NORDISKE ARBEJDSPAPIRER

NOR D I K K A A B E TS PAPPER

\section{Norden och EU starkare tillsammans}

- En rapport om hur nätverket mellan Nordiska Rådet och

Europaparlamentet kan stärkas

Andrea Karlsson

http://dx.doi.org/10.6027/NA2014-905

NA2014:905

ISSN 2311-0562

Detta arbetspapper är utgivet med finansiellt stöd från

Nordiska ministerrådet. Innehållet i arbetspappret

avspeglar inte nödvändigtvis Nordiska ministerrådets

synpunkter, åsikter eller anbefallningar. 



\section{Norden och EU}

\section{starkare tillsammans}

- En rapport om hur nätverket mellan

Nordiska Rådet och Europaparlamentet

kan stärkas

Andrea Karlsson

Praktikant i Nordiska rådet

Hösten 2013 


\section{Innehållsförteckning}

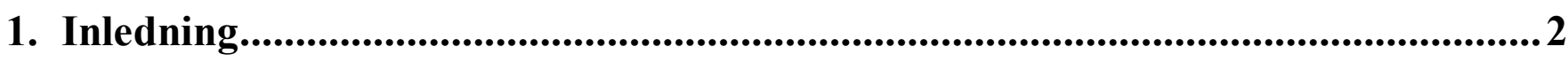

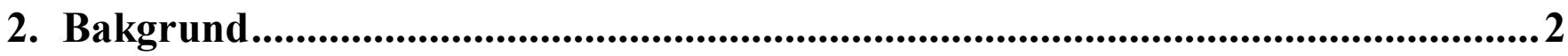

3. Förslag på åtgärder för att stärka nätverket................................................................4

3.1 Utbildning och information ............................................................................................6

Förslag 1: att Nordiska rådet på temasessionen 2015 arrangerar en "kontaktträff" mellan Nordiska rådets medlemmar och de nordiska Europaparlamentarikerna. 6

Förslag 2: att Nordiska rådets kommunikationsavdelning varannan eller var tredje månad skickar ut ett nordiskt elektroniskt nyhetsbrev till de nordiska Europaparlamentarikerna

Förslag 3: att delar av Nordiska rådets sekretariat, sekretariatskollegiet och/eller några från de nationella delegationssekretariaten ska göra en studietur till Bryssel.

Förslag 4: att Nordiska rådets medlemmar genom de nationella delegationssekreterarna, i högre grad ska bistå Nordiska rådets sekretariat samt partigruppssekretariaten med aktuell och relevant EU-information från de nationella parlamenten.

Förslag 5: att Nordiska rådet ska uppmana de nordiska regeringarna att tillsammans med Nordiska rådet och Nordiska ministerrådets sekretariat, hålla en utbildningsdag för tjänstemännen i ministerierna om Nordiska rådet och dess verksamhet, med diskussion bland annat om EU-koordineringen i Norden.

Förslag 6: att Nordiska rådets sekretariat med hjälp från delegationssekretariaten och Nordiska ministerrådet ska sammanställa och upprätthålla kontaktlistor över relevanta nordiska politiker och tjänstemän.

Förslag 7: att Nordiska rådets sekretariat inför varje verksamhetsår gör upp en prioriteringslista på två till tre aktuella EU-ärenden och som varje utskott ska arbeta med under året.

Förslag 8: att Nordiska rådet ska införa tematiska EU-debatter på varje session.

Förslag 9: att Nordiska rådet ska införa ett möte mellan ordförandena i de nationella parlamentens Europautskott/Stora utskott/Internationella utskott

Förslag 10: att Nordiska rådet i högre grad än tidigare ska bjuda in nordiska Europaparlamentariker till sina möten.

Förslag 11: att Nordiska rådet på sin årliga session ska anta gemensamma hållningar i relevanta EU-frågor som sedan meddelas de nordiska Europaparlamentarikerna.

Förslag 12: att Nordiska rådet ska uppmana regeringarna att ställa krav på sina tjänstemän om att tillsammans med sina nordiska kollegor diskutera, och eventuellt koordinera hur man bäst kan implementera ny EUlagstiftning, så att det inga nya gränshinder uppstår.

Förslag 13: att Nordiska rådet ska upprätta ett kontor i Bryssel med en permanent utsänd ämbetsman.....

Förslag 14: att Nordiska rådet ska tillsätta en ny tjänst i sekretariatet i Köpenhamn med huvudansvar på samarbetet med Europeiska unionen och Europaparlamentet. ...

Förslag 15: att Nordiska rådet genom sina rekommendationer ska uppmana de nordiska regeringarna att påverka EU:s ministerråd i relevanta EU-frågor. 
Förslag 16: att Nordiska rådet ska utöka sitt samarbete med parlamentariska organisationer så som Baltisk församling i syfte att arbeta med för båda, relevanta EU-frågor.

Förslag 17: att Nordiska rådet ska utöka sitt samarbete med parlamentariska organisationer så som Beneluxunionen i syfte att tillsammans arbeta med för båda, relevanta EU-frågor.

Förslag 18: att Nordiska rådet ska utöka sin kontakt med de nordiska ständiga representationerna i

Bryssel......

Förslag 19: att Nordiska rådet ska utöka sin kontakt med de nordiska regionkontoren i Bryssel...... 16

Förslag 20: att Nordiska rådet i högre grad ska använda sig av sociala medier i syftet att stärka kontakten till de nordiska Europaparlamentarikerna.

Förslag 21: att Nordiska rådet ska be om att få delta i EuroNest-möten i syfte att öka samarbetet kring Det Östra Partnerskapet.

3.3 EU i utskottsarbetet

Förslag 22: att Nordiska rådets utskott genom Europeiska kommissionens grön- och vitböcker även fortsättningsvis ska ge utlåtanden om ny EU-lagstiftning i frågor av nordisk relevans.

Förslag 23: att Nordiska rådets utskott i högre grad ska överväga möjligheterna att sända representanter till Bryssel eller Strasbourg för att delta i, eller själva arrangera seminarier, hearings eller möten om en specifik sakfråga.

Förslag 24: att Nordiska rådets utskott ska be om att få delta som observatörer vid Konferensen mellan de parlamentariska organen för EU-frågor vid Europeiska unionens parlament (COSAC) samt vid ordförandeskapsmöten då relevanta frågor tas upp på dagordningen....

Förslag 25: att Nordiska rådets utskott ska be om att få delta som observatörer vid de Interparlamentariska utskottsmötena organiserade av Europaparlamentets utskott, då relevanta frågor tas upp på dagordningen....

Förslag 26: att Nordiska rådets utskott ska be om att få delta på någon av de nordisk-baltiska frukostarna i Strasbourg

Förslag 27: att Nordiska rådets utskott i högre grad ska skapa och upprätthålla kontakter till nordiska Europaparlamentariker och tjänstemän i motsvarande Europaparlamentsutskott.

Förslag 28: att Nordiska rådets partigrupper ska arbeta för att öka kontakten med Europaparlamentets partigrupper både på politisk- och tjänstemannanivå. 


\begin{abstract}
Abstrakt
"Norden och EU - Starkare tillsammans" är en rapport om hur Nordiska rådets nätverk med EU/EES, och främst till Europaparlamentet kan stärkas. Med utgångspunkt i 62 intervjuer med nordiska Europaparlamentariker, medlemmar av Nordiska rådet, nordiska tjänstemän, representanter från nordiska regionkontor, ständiga representationer och andra relevanta personer inom det nordiska nätverket, har slutligen 28 konkreta - men även mer strategiska förslag till åtgärder lagts fram. Dessa redogörs för tillsammans med fördelar och nackdelar samt erfarenheter från de intervjuade, och tillika ges argument för varför ett stärkt nätverk anses nödvändigt. Främst handlar det om en önskan om ökade påverkningsmöjligheter i EU, ett större kontaktnät, ett ökat informationsflöde och möjligheten att sätta Nordiska rådet på den europeiska kartan. Syftet är att ge Nordiska rådets presidium flera konkreta förslag på hur man kan få till stånd ett ökat samarbete med relativt enkla medel.
\end{abstract}

Följande åtgärder föreslås i rapporten:

- 'Kontaktträff” med nordiska Europaparlamentariker på temasessionen 2015

- Nyhetsbrev mellan Nordiska rådet och Europaparlamentet

- Studietur till Bryssel

- Mer EU-information mellan sekretariatet och de nationella parlamenten

- Utbildningsdag om Nordiska rådet för tjänstemännen i de nationella ministerierna

- Kontaktlistor på tjänstemän och politiker

- Årlig EU-prioriteringslista för varje utskott

- Tematiska EU-debatter på sessionen

- Möten mellan de nationella parlamentens "EU-utskott"

- Fler Europaparlamentariker på Nordiska rådets möten

- Gemensamma nordiska EU-ståndpunkter till Europaparlamentet och ministerrådet

- Rekommendationer till regeringarna om nordisk översyn vid implementeringen av EU-lagar

- Utsänd ämbetsman i Bryssel eller "EU-tjänst" på Nordiska rådets sekretariat

- Ökat EU-samarbete med Baltisk Församling, Benelux-unionen och EuroNest

- Ökat samarbete med de nordiska ständiga representationerna och regionkontoren i Bryssel

- EU-information genom sociala medier

- Utlåtanden om kommissionens grön- och vitböcker

- Ökat deltagande på möten i Bryssel och Strasbourg

- Deltagande vid COSAC och andra interparlamentariska möten i Europaparlamentet

- Deltagande vid de nordisk-baltiska frukostarna i Strasbourg

- Mer kontakt mellan utskotten och partigrupperna i Norden och Europaparlamentet 


\section{Inledning}

Nordens roll i världen har förändrats. När Nordiska rådet grundades 1952 såg förutsättningarna och samverkan mellan de europeiska länderna väldigt annorlunda ut än det gör i dag och relationerna mellan flera länder var sköra. Då Danmark anslöt sig till Europeiska unionen 1973 ökade unionen från sex till nio medlemsländer och genom Sverige och Finlands medlemskap år 1995 omfattade det europeiska samarbetet femton länder i nästan hela Västeuropa. I dag består Europeiska unionen av 28 medlemsländer och flera kandidatländer väntar på att få gå med. Island och Norge är inte med i EU men är långtgående förenade genom sitt medlemskap i Europeiska Ekonomiska Samarbetsområdet (EES) och Schengenområdet. Grönland följde - till skillnad från Färöarna - med Danmark in i EG 1973 men valde att lämna unionen 1985, ett par år efter att de fătt Hjemmestyre. Idag är såväl Grönland som Färöarna utanför EU och är heller inte med i EES eller Schengen. Vad gäller Åland så valde de att gå med i EU i samband med Finlands inträde i unionen. I Norden är det endast Finland och Åland som har valt att gå med i Ekonomiska och monetära unionen (EMU) och de har därmed euron som valuta. De nordiska länderna samt Färöarna, Grönland och Åland har tillsammans 25 miljoner invånare och utgör sammantaget världens tionde största ekonomi.

Samtidigt som det europeiska samarbetet har utökats har även dess verksamhet och lagstiftning blivit allt mer omfattande. I dag beräknas EU:s lagstiftningsområden, beroende på mätmetoder, påverka omkring 30 procent av den nationella lagstiftningen. Enligt Sveriges Kommuner och Landsting (SKL) beräknas emellertid en större andel, cirka 60 procent, antingen direkt eller indirekt påverka den regionala- och kommunala nivån i Sverige. Denna andel skiljer sig givetvis åt mellan de nordiska länderna, men ger ändå en god indikation på hur stor inverkan EU faktiskt har på medborgarnas liv. Och faktum är att en stor del av frågorna som i dag tas upp till behandling $\mathrm{i}$ Nordiska rådet har en europeisk koppling. Att vara insatt i vad som händer i EU-städerna Bryssel och Strasbourg är därför fundamentalt för att Nordiska rådet ska ha en möjlighet att påverka i de olika frågorna. Men även omvänt finns mycket att vinna. Det nordiska samarbetet är unikt och det finns flera exempel på frågor där EU kan lära av Norden. Den nordiska modellen är välkänd och har granskats mycket internationellt. Ett stärkt nätverk mellan Nordiska rådet och Europaparlamentet är betydelsefullt för båda parter och med rätt verktyg finns mycket att vinna.

Denna rapport avser därför, att genom intervjuer med medlemmar och tjänstemän från Nordiska rådet, nordiska Europaparlamentariker i Bryssel samt andra relevanta ämbetsmän och politiker inom det nordiska nätverket, ta fram förslag på hur samarbetet mellan Nordiska rådet och Europaparlamentet kan stärkas. En uttömmande lista på de intervjuade finns i slutet av rapporten.

\section{Bakgrund}

En av Nordiska rådets första aktiva åtgärder för att rikta blicken mot EU var på sessionen i Stockholm 2009 då man antog en gemensam EU-strategi. Sverige hade inte bara ordförandeklubban i Nordiska rådet, utan ledde även arbetet i Europeiska unionens råd under andra halvan av året, vilket gjorde "Norden och EU" till ett aktuellt sessionstema på flera plan. Det tillsammans med det svenska delegationsförslaget om att Nordiska rådet skulle ges möjlighet att yttra sig om EU:s grön- 
och vitböcker i frågor av nordisk relevans, var en del av det påbörjade arbetet mot att mer systematiskt arbeta med EU-frågor som är viktiga för Norden.

Två år senare, år 2011, godkände presidiet en uppdaterad EU-strategi på Nordiska rådets session i Köpenhamn. Denna fick namnet "En nordisk stämma i EU", vilket samma sommar även blev temat för ett möte i Europaparlamentet mellan presidiet och flera av de nordiska Europaparlamentarikerna. I denna uppdaterade strategi framhöll presidiet att samarbetet med EU, och särskilt Europaparlamentet, är viktigt då allt fler ärenden och politikområden avgörs just där. Man betonade att de nordiska länderna i många frågor har gemensamma intressen och att dessa borde framföras i EU/EES. Målet med strategin var att göra en samnordisk insats på de områden där de nordiska länderna har likartade åsikter. Man motiverade detta med att det $\mathrm{i}$ en union med 27 medlemsländer (i dag 28 stycken), blir allt viktigare med disciplin och förarbete. Det senaste steget i Nordiska rådets strävan mot ett ökat EU-inflytandet var i juni 2012 då presidiets EU-rapportör Bertel Haarder besökte Europaparlamentet i Strasbourg för att möta nordiska Europaparlamentariker. Då diskuterades frågan om hur man kunde öka samarbetet och många viktiga synpunkter framfördes, av vilka flera återkommer i denna rapport. Nordiska rådets utskott har under de senaste åren även sporadiskt besökt Bryssel för att delta i möten och seminarier.

År 2014 är det återigen Sverige som bär ordförandeklubban i Nordiska rådet och temat för ordförandeskapsprogrammet är "Norden i Europa - Europa i Norden”. "Det är av största vikt att vi i Norden tar det europeiska samarbetet på allvar och utnyttjar vår position till fullo", står det i programmet som också påpekar att Europaparlamentsvalet närmar sig och att en ny kommission kommer att tillsättas. Det är således ett enastående tillfälle för Nordiska rådet att skapa nya kontakter och inflytandemöjligheter i den europeiska politiken.

Diskussionerna om ett ökat samarbete mellan Nordiska rådet och EU/EES har som ovan beskrivits, pågått i flera år och utmynnat i många argument till varför EU-strategin anses nödvändig. Främst handlar det om att skapa ökade påverkningsmöjligheter och informationskanaler för båda parter. Även fast utgångslägena och intresseområdena varierar mellan de nordiska länderna, så anser de allra flesta att det finns många frågor som EU och Norden skulle tjäna på att samarbeta kring och det finns flera exempel på situationer där nordiskt samarbete skulle behövas för att lösa problem eller för att backa upp ett annat nordiskt land. Ett aktuellt exempel är Grönland i Arktisfrågan. Ett annat är samerna, som är EU:s enda ursprungsbefolkning. Nordiska rådet kunde även bidra med erfarenheter i frågor där man har stort kunnande. Ett annat argument är styrkan i att hålla samman för att höras bättre; när unionen får allt fler medlemmar tenderar varje medlemslands röst att bli svagare, och ett enigt Norden ljuder helt enkelt högre bland alla 28 röster i EU. En nordisk röst på 25 miljoner medborgare har stor tyngd och "den nordiska regionen" har stor potential att bli en stark aktör i EU. Och om Norden har möjlighet att påverka EU:s politik i den riktning som man från ett nordiskt perspektiv anser vara det riktiga, så menar många att man ska göra det. Vidare anser några att det är tankeväckande att Nordiska rådets verksamhet i EU/EES är så marginell jämfört med kontakterna och samarbetet som finns med öst. 
Att Island och Norge är utanför unionen anses inte vara ett hinder, utan snarare en orsak till varför detta behövs. Länderna följer nämligen omkring 80 procent av EU:s lagstiftning genom EES, vilket gör ett ökat inflytande viktigt även för dem. Också för Färöarna och Grönland finns ett behov av att göra sina röster hörda och då är Nordiska rådet en bra kanal. Lyssnar man på de mer EU-kritiska medlemmarna av Nordiska rådet så ser de generellt fler fördelar med att vara med i spelet och försöka påverka, än att inte vara involverade alls. Faktum är att de beslut som fattas i Bryssel påverkar de nordiska medborgarna oavsett. Ett annat viktigt argument till varför ett starkare samarbete mellan Norden och EU behövs har framförts av Utrikespolitiska institutet i Finland. I deras rapport "Norden - Making a Difference? Possibilities for enhanced Nordic cooperation in international affairs. The Norden 2020 project report" framkommer det att små stater i en global kontext riskerar att bli allt mer marginaliserade i beslutsprocesserna. Det beror till stor del på att de länder med mest makt och resurser allt oftare går samman och fattar besluten i grupper så som G20. Enligt rapporten ligger lösningen $\mathrm{i}$ att de nordiska länderna tillsammans under det nordiska varumärket, för fram sina ståndpunkter. Hittills har detta dock varit mera undantag än regel.

En följd av ett stärkt nätverk kan även vara en ökad samverkan mellan de nordiska Europaparlamentarikerna i Bryssel. Mer nordiskt samarbete i Europaparlamentets utskott eller partigrupper kan alltså leda till större inflytande och ökade chanser till viktiga politiska poster. För Nordiska rådets sida är fördelarna också många. Effekterna av ett starkare nätverk väntas bland annat vara en högre vetskap om vad som är aktuellt i Europa, påverkningsmöjligheter i frågor av nordisk nytta, möjligheter till fler betydelsefulla kontakter också utanför Europaparlamentet samt ett starkare nordiskt varumärke i Europa. I dagsläget upplever många att Nordiska rådet är ett eller flera steg efter i den europeiska lagstiftningsprocessen, vilket kan ställa till problem i implementeringsfasen då gränshinder mellan de nordiska länderna kan uppkomma. Det är en stor orsak till varför Nordiska rådet borde vara mer proaktiva och involverade i den EU-lagstiftning som påverkar Norden.

\section{Förslag på åtgärder för att stärka nätverket}

Ett första steg i arbetet med att öka samarbetet mellan Nordiska rådet och EU/EES är att identifiera de frågor och sakområden som är aktuella i EU, som påverkar Norden och där det finns en faktisk nordisk nytta att försöka påverka (se illustration nedan). Vilka direktiv är på gång och hur långt i beslutsprocessen har man kommit? Gagnar det Norden att arbeta med dessa? Därefter bör man diskutera den aktuella frågan och pröva att finna en gemensam nordisk ståndpunkt - om inte för hela direktivet - så i alla fall till utvalda delar. Det är avgörande att komma in så tidigt som möjligt i processen. När man har identifierat frågorna är det fundamentalt att prioritera, det är omöjligt att arbeta med allt. Och först därefter kan man börja fundera på vilka verktyg man ska använda för att nå målen. Förslagen som presenteras i denna rapport kan liknas vid dessa verktyg.

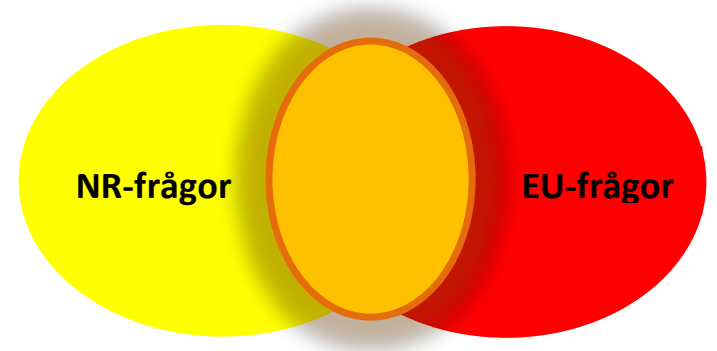

Cirkeln $i$ orange färg illustrerar de frågor som är aktuella $i$ EU, påverkar Norden och där det finns en faktisk nordisk nytta med att försöka påverka 
Det finns en mångfald politikområden som är viktiga för de nordiska länderna och som man kunde arbeta med på EU-nivå. Dit hör bland annat Östersjöstrategin, Arktis och den nordliga dimensionen, men även en fri arbetsmarknad, infrastruktur, kollektivavtal, ungdomsarbetslöshet samt forskning och innovation. Vidare anger flera att utrikes- försvars- och säkerhetspolitik, lantbruks- och fiskeripolitik, livsmedelsfrågor, havs- och skogsvård, konsumentpolitik, regionalpolitik, antikorruption samt transportfrågor är viktiga politikområden för Norden. Särskilt på energi, -miljöoch gränshindersområdet anses de nordiska länderna ha goda erfarenheter och det finns ett växande intresse för den nordiska modellen i Europa. I intervjuerna anger de flesta att även om det råder en mångfald politiska uppfattningar i de nordiska länderna så finns ändå en gemensam värdegrund som baserar sig på jämställdhet, demokrati, det nordiska välfärdssamhället, transparens, individens frihet, barnens och djurens rättigheter samt den fria rörligheten. Man påpekar att Norden har en annan rättstradition än i övriga Europa och att man genom samarbete kan säga ja tillsammans - men även nej då det behövs. Man varnar dock för att i allt för hög grad tala om för andra hur saker ska göras. Ett lyckat exempel på samarbete mellan Nordiska rådet och de nordiska Europaparlamentarikerna var när man i Europaparlamentets miljö, - folkhälsa och livsmedelssäkerhetsutskott (ENVI) i november 2012 röstade om direktivet om antibiotikaresistens och veterinärers rätt att sälja antibiotika (One Health-direktivet). Då hade Nordiska rådets medborgar- och konsumentutskott diskuterat direktivet och kunde genom en av Nordiska rådets medlemmar, skicka sina åsikter direkt till berörda nordiska Europaparlamentariker som satt i ENVIutskottet. Responsen från Europaparlamentarikerna var positiv och omröstningsresultatet blev det önskade.

Ett bekymmer som har framförts är samarbetets initialstadie. Många av de nordiska Europaparlamentarikerna har angett att de gärna inleder ett ökat samarbete men att initiativet måste komma från Nordiska rådet. Men hur tar man de första stegen mot ett starkare nätverk? Var ska man börja? Någon gemensam nordisk plattform i EU existerar egentligen inte i dagsläget, men Nordiska rådet utgör en unik och formell grund att arbeta från. Det är dock inte realistiskt att tro att man kan genomföra alla förslag på en gång - det är ett arbete som tar tid. Här måste man vara realistisk och som en av de intervjuade uttryckte sig: "börja i den ända man är överens om". Det lönar sig inte att försöka nå konsensus i en fråga där de nordiska länderna står långt ifrån varandra. Istället bör man börja med de politikområden där minst variationer råder och sedan efter hand bredda samarbetet.

Nedan följer således olika förslag på såväl konkreta som mer strategiska åtgärder som kan genomföras för att stärka nätverket mellan Nordiska rådet och EU/EES, och då i första hand till Europaparlamentet. Förslagen redogörs för i fetstilt text och är för tydlighetens skull kategoriserade i olika tematiska underrubriker. Under varje förslag diskuteras idén i en löpande text där både tidigare erfarenheter samt förslagets för- och nackdelar behandlas. Vilka förslag som sedan genomförs lämnas till Nordiska rådets presidium att bestämma. En konkluderande sammanfattning 
hittas i den avslutande delen "Avslutning". Viktigt att ha i åtanke när man läser rapporten är att inget förslag ensamt kan uppfylla målet om ett stärkt nätverk, utan bör för bästa möjliga resultat kombineras med flera. Vilka förslag som i slutändan genomförs är självklart avhängigt på de resurser som finns. Framgången är i många avseenden även beroende av den politiska viljan samt att få rätt person på rätt plats. Noteras bör slutligen att alla synpunkter och förslag i rapporten baseras på de svar som har getts i intervjuerna.

\subsection{Utbildning och information}

För att kunna identifiera de för Norden relevanta EU-frågorna krävs en grundläggande kunskap i Europeiska unionens uppbyggnad, verksamhet och beslutsprocesser. Hur fattas beslut i EU och när i processen finns det störst chans att påverka? Vilka personer jobbar i Europaparlamentet och i Nordiska rådet samt i vilka utskott? Vad är aktuellt i både Norden och EU och finns det en nordisk nytta att försöka påverka? Det är grundläggande frågor man måste ha klart för sig för att kunna stärka nätverket. Här nedan följer således förslag på hur Nordiska rådet genom just utbildning och information, kan öka sitt samarbete med EU/EES.

Förslag 1: att Nordiska rådet på temasessionen 2015 arrangerar en "kontaktträff" mellan Nordiska rådets medlemmar och de nordiska Europaparlamentarikerna

Nordiska rådet kunde på temasessionen 2015 arrangera en så kallad 'kontaktträff' mellan Nordiska rådets medlemmar och nordiska Europaparlamentariker. Temasessionen planeras nämligen ta plats $i$ Bryssel under temat "Norden och EU" och skulle vara ett perfekt tillfälle för en "kontaktträff', där man kunde bredda kontaktnätet och få information om EU. Europaparlamentariker kunde ges möjlighet att hålla anförande om ett aktuellt EU-ämne och träffen kunde bestå av en föreläsning om Europeiska unionens verksamhet för att lära sig om när man har bäst möjligheter att påverka och genom vilka kanaler. Samtidigt kunde information ges om vad som är på gång inom det nordiska samarbetet och i de nationella parlamenten. Därutöver kunde man ge ut en lista på vilka personer som representerar Sverige, Finland och Danmark i Europaparlamentet de fem kommande åren, i vilka utskott de sitter samt kontaktuppgifter till dessa (se förslag 6).

Fördelar: Man slår flera flugor i en smäll; förutom att utbyta relevant information, skapa kontakter till de nyinvalda nordiska Europaparlamentarikerna och upprätthålla de redan etablerade kontakterna hos dem som har fått fortsatt förtroende, får man även möjlighet att diskutera en aktuell EU-fråga i form av ett seminarium. En annan fördel är det stora deltagarantalet från Nordiska rådet, då man likaväl kan ha temasessionen i Bryssel, som att vara i någon av de nordiska städerna. Antalet Europaparlamentariker skulle dessutom vara betydligt flera om "kontaktträffen" arrangerades i Bryssel.

Nackdelar: Detta förslag innebär mycket förberedelse och höga kostnader.

Förslag 2: att Nordiska rådets kommunikationsavdelning varannan eller var tredje månad skickar ut ett nordiskt elektroniskt nyhetsbrev till de nordiska Europaparlamentarikerna 
Det är inte bara Nordiska rådet som har nytta av information från EU, informationsflödet behöver även gå i motsatt riktning. Flera nordiska Europaparlamentariker menar att det är svårt att hålla sig uppdaterade om vilka frågor som är aktuella i Norden och har därför visat intresse för att med jämna mellanrum få nyhetsbrev från Nordiska rådet. Förslaget är att Nordiska rådets kommunikationsavdelning i samarbete med den ansvariga på Nordiska rådets sekretariat, varannan eller var tredje månad skickar ut någon form av elektroniskt nyhetsbrev till de nordiska Europaparlamentarikerna.

Fördelar: Fördelen med nyhetsbrev är förutom själva informationsaspekten, även att Europaparlamentarikerna påminns om "det nordiska perspektivet" i sitt arbete. Det är dessutom en billig åtgärd.

Nackdelar: Nyhetsbreven bör skrivas så att dess innehåll är relevant för Europaparlamentarikern och att de inte skickas ut för ofta.

Förslag 3: att delar av Nordiska rådets sekretariat, sekretariatskollegiet och/eller några från de nationella delegationssekretariaten ska göra en studietur till Bryssel

Nordiska rådets sekretariats uppgifter är att förbereda och följa upp de frågor som behandlas i Nordiska rådets ledningsorgan, presidiet och i de olika fackutskotten. Det vore därför viktigt att inte bara politikerna, utan även att de personer som arbetar med EU-frågor i sekretariatet och sekretariatskollegiet har god kunskap om EU. Därför föreslås att delar av sekretariatet, sekretariatskollegiet och/eller några från de nationella delegationssekretariaten, ska göra en studietur till Bryssel i syfte att lära sig mera om det europeiska samarbetet. En möjlighet vore att sekretariatskollegiet gör en studietur till Bryssel och i samband med det håller sitt möte där. Samtidigt kunde man träffa relevanta personer från Europaparlamentet, de ständiga representationerna, de nordiska regionkontoren eller nordiska lobbyingorganisationer för att lära sig mera om deras verksamhet. En sådan studietur behöver inte göras väldigt ofta, utan kan arrangeras i samband med att sekretariatet har fătt många nya anställda eller att det har gjorts stora omorganiseringar på europeisk nivå.

Fördelar: Man får en god överblick över vilka aktörer som finns i Bryssel och kan knyta många kontakter. Antalet deltagare kan begränsas till de som direkt arbetar med EU-frågor.

Nackdelar: En studietur till Bryssel med många deltagare är dyrt. Vidare bör programmet vara välplanerat för att få så mycket som möjligt ut av turen.

Förslag 4: att Nordiska rådets medlemmar genom de nationella delegationssekreterarna, $i$ högre grad ska bistå Nordiska rådets sekretariat samt partigruppssekretariaten med aktuell och relevant $\mathrm{EU}$-information från de nationella parlamenten

Flera intervjuade påpekar att man inte får glömma att de nationella parlamentarikerna faktiskt får mycket kunskap och information om EU/EES i sitt arbete på hemmaplan. Det är alltså inte bara från Europaparlamentet som de aktuella EU-upplysningarna till Nordiska rådets sekretariat bör komma, utan även från Nordiska rådets medlemmar, genom de nationella delegationssekretariaten. 
Dessutom bör man dra fördel av de medlemmar från Nordiska rådet som är med i de nationella EUutskotten. Förslaget är därför att Nordiska rådets medlemmar, och särskilt de som sitter i de nationella EU-utskotten, systematiskt ska hålla Nordiska rådets sekretariat och partigruppssekretariat uppdaterade om viktiga EU-nyheter. Det görs med fördel genom de nationella delegationssekretariaten. På Nordiska rådets utskottsmöten kunde det dessutom införas en fast punkt på agendan där Nordiska rådets medlemmar kunde lyfta fram och diskutera relevanta EU-saker.

En annan möjlighet med samma ändamål vore att varje nationell delegation utsåg en "EU-ansvarig" bland medlemmarna, vars uppgift vore att uppdatera presidiets EU-rapportör om aktuella EU-frågor från de nationella parlamenten som har en nordisk koppling. De åtta "EU-ansvariga" från varje nationell delegation kunde regelbundet träffa EU-rapportören för en avstämning.

Fördelar: Det är en kostnadsfri och oerhört viktig åtgärd som gör EU-frågorna till en mer integrerad del av Nordiska rådets arbete. Det fyller även en annan viktig funktion då politikerna genom det ökade informationsflödet, mer frekvent påminns om "det nordiska perspektivet" i sitt arbete.

Nackdelar: Det kan till en början vara utmanande för politikerna att skapa formerna för informationsutbytet. Det krävs både samarbete och vilja från politikern och dess tjänstemän.

Förslag 5: att Nordiska rådet ska uppmana de nordiska regeringarna att tillsammans med Nordiska rådet och Nordiska ministerrådets sekretariat, hålla en utbildningsdag för tjänstemännen i ministerierna om Nordiska rådet och dess verksamhet, med diskussion bland annat om EU-koordineringen i Norden

Kunskap är grunden för förståelse och i dag är kännedomen om Nordiska rådet bland tjänstemännen i de nordiska ministerierna tyvärr rätt låg. Detta kunde delvis lösas genom att Nordiska rådet uppmanar de nordiska regeringarna att i samarbete med Nordiska rådet och Nordiska ministerrådets sekretariat, hålla en utbildningsdag för tjänstemännen i ministerierna om vad Nordiska rådet är samt vad som ingår $\mathrm{i}$ dess verksamhet. Samtidigt kunde man ha en diskussion om bland annat koordineringen av EU-ärenden i Norden. Utbildningsdagen kunde arrangeras nationellt, men Nordiska rådet kunde ordna med utbildningsmaterial.

Fördelar: Genom att öka kunskapen om Nordiska rådets verksamhet kan man på sikt öka samarbetet mellan de nordiska tjänstemännen. Detta kan bidra till en ökad samordning vid implementeringen av ny EU-lagstiftning och att färre gränshinder uppstår mellan de nordiska länderna.

Nackdelar: Någon ska bistå de nationella regeringarna i arrangerandet av utbildningsdagen. Man kan mötas av kritik från ministerierna om behovet av en utbildningsdag om Nordiska rådet.

Förslag 6: att Nordiska rådets sekretariat med hjälp från delegationssekretariaten och Nordiska ministerrådet ska sammanställa och upprätthålla kontaktlistor över relevanta nordiska politiker och tjänstemän 
Ett konkret och viktigt verktyg för att enkelt kunna ta kontakt med relevanta personer är olika elektroniska kontaktlistor. Efter Europaparlamentsvalet i maj 2014 bör Nordiska rådets sekretariat sammanställa en lista på de politiker som representerar Sverige, Finland och Danmark i Europaparlamentet de fem kommande åren, i vilka utskott och arbetsgrupper de sitter samt kontaktuppgifter till dessa. Det är betydligt lättare för Nordiska rådets politiker och tjänstemän att ta kontakt om de vet vilka personer som arbetar med vilka frågor. Omvänt bör de nordiska Europaparlamentarikerna få kontaktuppgifter till Nordiska rådets sekretariat, delegationssekreterare, partisekreterare och utskottssekreterare med en kort beskrivning på vilka de kan kontakta i olika ärenden.

En annan användbar kontaktlista är på de tjänstemän som på något vis arbetar med EU-frågor i de nationella parlamenten. Dit hör till exempel de olika EU-utskottens (Stora utskottet, Internationella utskottet etc.) tjänstemän. Syftet är dels att öka kopplingen mellan de nordiska ländernas parlament och Nordiska rådet på tjänstemannanivå, dels att lättare kunna dela relevant information samt svara på varandras frågor. Nordiska rådets delegationssekretariat kunde få i uppgift att sammanställa denna lista.

Vidare är en lista över de nordiska tjänstemän som arbetar i Europaparlamentet praktisk. Det finns många personer från Norden som arbetar i partigruppssekretariaten, utskottssekretariaten eller med andra uppgifter, och dessa kan det vara bra att kunna kontakta. Nordiska rådets sekretariat kunde därför be de personer som arbetar mot Europaparlamentet i de nordiska ständiga representationerna i Bryssel att sammanställa en sådan lista, eftersom de oftast redan har de kontakterna. Där borde även tjänstemännens huvudsakliga ansvarsområden framkomma, så att man från Nordiska rådets sida vet vem man kan kontakta i vilka frågor.

Slutligen kunde Nordiska rådet be Nordiska ministerrådet att sammanställa och upprätthålla en kontaktlista på de tjänstemän som arbetar i de nationella ministerierna, i syfte att göra samarbetet kring EU-frågor lättare. Särskilt vid implementeringen av ny EU-lagstiftning skulle det vara viktigt att lätt kunna ta kontakt med sina nordiska kollegor. Listan behöver inte vara uttömmande, men tillräcklig för att man ska finna kontaktuppgifter till någon i varje ministerium.

Det är viktigt att listorna distribueras till alla medlemmar, assistenter och tjänstemän och uppdateras kontinuerligt då ändringar sker.

Fördelar: Kontaktlistor är ett enkelt, konkret och kostnadsfritt verktyg som underlättar kontakterna. Vidare är det viktigt att inte bara bygga broar mellan de nordiska och europeiska politikerna, utan att även skapa kontakter på tjänstemannanivå. Det här är även en metod som kopplar samman "EUtjänstemän" mellan de nationella parlamenten.

Nackdelar: Det tar tid att sammanställa listorna och de måste ständigt uppdateras för att hållas aktuella. Vidare är det möjligt att några opponerar sig mot kontaklistan på de nordiska tjänstemännen i Europaparlamentet eftersom dessa inte arbetar nationellt.

\subsection{EU i den löpande verksamheten}


I Nordiska rådets EU-strategi "En nordisk stämma i EU" från 2011 efterlyser man ett mer systematiserat EU-arbete och anger att det saknas ett ordentligt samordnande i sådana ärenden. Många menar att man alltid är steget efter och att ny EU-lagstiftning upptäcks för sent för att det ska finnas en reell chans att påverka. Konsekvensen är att man i implementeringsstadiet ibland upptäcker att lagen ställer till bekymmer för de nordiska medborgarna, något man kanske hade kunnat förhindra. Nedan följer således förslag på hur Nordiska rådet kan arbeta för att EU-frågorna ska bli en naturlig del av det löpande arbetet. Förslagen ska inte göra arbetsbördan tyngre för de berörda, istället är förhoppningen att planering och systematisering ska underlätta arbetet och sätta tydligare ramar och riktlinjer som man kan falla tillbaka på.

\section{Förslag 7: att Nordiska rådets sekretariat inför varje verksamhetsår gör upp en prioriteringslista på två till tre aktuella EU-ärenden som varje utskott kan arbeta med under året}

Tydliga mål och strategier är essentiellt för ett framgångsrikt arbete. I dag uppfattar många EUfrågorna som en avskild och betungande del av verksamheten och direktiven anses vara en djungel. Nordiska rådets utskott arbetar ganska olika med EU-ärendena, och flera upplever att nya direktiv oväntat dyker upp och skapar stress. Också Nordiska rådets partigrupper har efterlyst mer sorterad information för att fă styrning och för att kunna delegera ut konkreta uppgifter till de nationella ledamöterna. Målet borde därför vara att inkorporera EU-frågorna i det dagliga arbetet och istället för betungande, ska prioriteringarna skapa ett mer målinriktat arbete. Förslaget är alltså att Nordiska rådets sekretariat inför varje nytt verksamhetsår gör en prioriteringslista på två eller tre EU-ärenden som varje utskott kan arbeta med under året. Dessa ärenden ska ha nordisk relevans, vara frågor där Nordiska rådet har en faktisk chans att påverka eller rent allmänt vara direktiv som är aktuella. Som hjälp kan man på samma vis som tidigare använda danska folketingets årliga EU-prioriteringslista och Europeiska kommissionens arbetsprogram. Därutöver är det viktigt att vara beredd på att ta sig an ad hoc-ärenden under året.

För att praktiskt underlätta för varje utskott kan man förutom att göra EU-prioriteringar, även utarbeta strategier för hur man kan arbeta med varje fråga under året samt utstaka konkreta mål för vad man vill åstadkomma. Eftersom det överordnade ansvaret för Nordiska rådets relationer med EU tillfaller presidiet ska EU-prioriteringarna och strategierna även presenteras för dem. Presidiets EU-rapportör bör hållas uppdaterad om ärendena under året. För att göra de nordiska Europaparlamentarikerna uppmärksammande om vad som står högst upp på Nordiska rådets EUagenda kunde prioriteringarna även presenteras för dem. Det kan eventuellt leda till lite mer "nordiskt tänk" i deras arbete samt ett informationsutbyte om ärendenas gång.

Fördelar: Prioriteringar, strategier och mål ger tydliga riktlinjer som underlättar för de personer som arbetar med det.

Nackdelar: Det är tidskrävande att sammanställa prioriteringar och strategier och det kräver en del efterforskningar för att veta vad som är aktuellt.

Förslag 8: att Nordiska rådet ska införa tematiska EU-debatter på varje session 
Att göra tematiska EU-debatter till en fast punkt på Nordiska rådets årliga session är viktigt för att skapa diskussion om frågor som är politiskt aktuella i både Norden och EU. Det ökar den nordiska koordineringen av EU-frågor och kanske kan man nå en nordisk konsensus i en fråga, eller vissa delar av en fråga, som man sedan kan föra vidare på europeisk nivå.

Fördelar: Det är relativt enkelt att införa tematiska EU-diskussioner eftersom "internationellt samarbete" redan finns som en punkt på sessionsdagordningen. Dessutom ger det en uppfattning om hur opinionerna går bland Nordiska rådets medlemmar och utgör en konkret orsak till att bjuda in nordiska Europaparlamentariker till sessionen.

Nackdelar: Sessionsdagordningen är redan fullspäckad av punkter.

\section{Förslag 9: att Nordiska rådet ska införa ett möte mellan ordförandena i de nationella parlamentens Europautskott/Stora utskott/Internationella utskott}

På samma sätt som de nationella parlamentens talmän träffas för ett talmansmöte på sessionen så kunde man införa möten mellan ordförandena $\mathrm{i}$ de nationella parlamentens EU-utskott (Europautskottet, Stora utskottet, Internationella utskottet etc.). Ett sådant möte kunde förslagsvis ta plats under sessionen eller i anknytning till Europaparlamentets COSAC-möten, då ordförandena från de nationella parlamentens EU-utskott träffas. Syftet är att stärka kopplingen mellan de nationella parlamenten och Nordiska rådet i EU-frågor, men även för att öka medvetenheten om Nordiska rådets arbete på ett nationellt plan och för att utbyta "best practises". Om mötet tar plats under sessionen kunde ordförandena först träffas på egen hand för att diskutera EU-frågor av gemensamt nordiskt intresse och sedan kompletteras av politiker från Nordiska rådet (antingen presidiemedlemmarna eller de medlemmar som sitter i de nationella EU-utskotten). Man behöver inte alltid vara av samma åsikter, huvudsaken är att man lyfter EU-frågor till diskussion för att veta vad som är intressant $i$ de nordiska länderna.

Fördelar: Mötena skulle fungera som ett forum för de nationella politikerna att mötas samtidigt som ordförandena får höra hur tongångarna går på ett nordiskt plan, vilket eventuellt kan leda till mera "nordiskt tänk" i det nationella arbetet. Generellt anses kopplingen mellan de nationella parlamenten och Nordiska rådet vara bristfällig. Detta är en metod som knyter ihop dessa två bättre.

Nackdelar: Flera är kritiska till flera arbetsgrupper och fasta möten eftersom de har en tendens att bli "hackade i sten" och sedan inte går att ändra. Flera vill hellre ha en mera ad hoc-liknande grupp.

\section{Förslag 10: att Nordiska rådet $\mathrm{i}$ högre grad än tidigare ska bjuda in nordiska Europaparlamentariker till sina möten}

Nordiska rådet har sedan länge skickat ut inbjudningar till sina möten såväl till nordiska Europaparlamentariker som till SINEEA-delegationen, som är Nordiska rådets formella kontakt i Europaparlamentet. Som en del i strävan om att stärka nätverket är det dock på sin plats att göra invitationerna till Europaparlamentarikerna mer systematiserade. När man på sessionen eller på temasessionen har tematiska EU-diskussioner bör man bjuda in de nordiska Europaparlamentariker som sitter i motsvarande utskott och arbetar med frågan. Parlamentarikern bör även få möjlighet till 
att hålla ett tal för att informera om sakens gång i Europaparlamentet. Om Europaparlamentarikern får en förfrågan om att tala om en fråga som är kopplat till dennes uppdrag i Europaparlamentet, så ersätter parlamentet resan. Utöver talet i plenum, kunde Europaparlamentarikern under mötesdagen även få möjlighet att hålla ett rundabordssamtal med Nordiska rådets partigrupper eller utskottsgrupper, för att få så mycket ut av deltagandet som möjligt. De flesta av de intervjuade Europaparlamentarikerna anger att deras tidsscheman är ytterst pressade och att de många gånger just av den orsaken har tackat nej. Det går inte alltid att ta hänsyn till, men generellt är det mer sannolikt att Europaparlamentarikerna kan delta på möten i Norden under en så kallad "grön vecka" eller på fredagar. Måndagar till torsdagar tenderar de att vara mer bundna till kontoret i Bryssel eller Strasbourg. I intervjuerna anger dock de flesta att de nog kan finna tid till att delta om mötet är tillräckligt konkret, intressant och inriktat på en sakfråga.

Fördelar: En stor fördel med detta förslag är det värdefulla EU-perspektiv det tillför mötena, men även det nätverk man har möjlighet att skapa. Om Europaparlamentarikern får hålla ett tal som har en koppling till utövandet av dennes uppdrag i Europaparlamentet, så kostar det ingenting för Nordiska rådet.

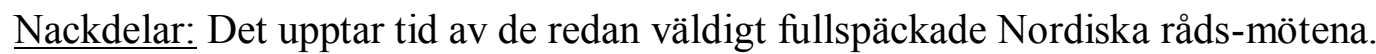

\section{Förslag 11: att Nordiska rådet på sin årliga session ska anta gemensamma ståndpunkter i relevanta EU-frågor som sedan delges de nordiska Europaparlamentarikerna}

På samma vis som man antar rekommendationer till de nationella regeringarna, kunde man på Nordiska rådets session även anta gemensamma ståndpunkter i relevanta EU-frågor och direktiv. Dessa kunde sedan delges de nordiska Europaparlamentarikerna för att klarlägga den nordiska ståndpunkten tillsammans med en uppmaning om att de tas till beaktande i deras arbete. Där skulle det även redogöras för varför det skulle vara viktigt för de nordiska medborgarna.

Fördelar: Möjligheten till att ge gemensamma ståndpunkter i EU-frågor kan eventuellt driva Nordiska rådet till att oftare nå konsensus. Det kan även vara till nytta för Europaparlamentarikerna som får en uppfattning om hur opinionerna är i Norden.

Nackdelar: Det kan uppfattas som att Nordiska rådet ger ut befallningar till de nordiska Europaparlamentarikerna och i stället för ett gott samarbete kan det ge motsatt effekt.

Förslag 12: att Nordiska rådet ska uppmana regeringarna att ställa krav på sina tjänstemän om att tillsammans med sina nordiska kollegor diskutera, och eventuellt koordinera hur man bäst kan implementera ny EU-lagstiftning, så att det inga nya gränshinder uppstår

Enligt detta förslag skulle Nordiska rådet uppmana de nordiska regeringarna att ställa krav på sina tjänstemän att i diskussion med sina nordiska kollegor, finna ett sätt att koordinera hur man bäst kan implementera nya EU-direktiv. Syftet är att försöka förhindra att nya gränshinder uppstår mellan de nordiska länderna när ny EU-lagstiftning träder i kraft och i dag existerar ingen sådan samordning. Detta kunde exempelvis göras genom att man inför en "nordisk jämförelse" på samma vis som man 
till exempel i Finland i dag gör en "internationell jämförelse". Syftet är även att öka dialogen över landsgränserna.

Fördelar: Det skulle dels öka samarbetet mellan de nordiska tjänstemännen i de olika ministerierna, dels minska på de gränshinder som ibland uppstår då de nordiska länderna implementerar ny EUlagstiftning på skilda håll.

Nackdelar: EU-arbetet är organiserat på olika sätt i de nordiska länderna, vilket inte gör det möjligt att ställa detaljerade krav på hur samarbetet mellan tjänstemännen ska ske. Vidare kan tjänstemännen uppfatta åtgärden som krävande innan man fătt in rutin.

\section{Förslag 13: att Nordiska rådet ska upprätta ett kontor i Bryssel med en permanent utsänd ämbetsman}

En naturlig och enligt många rentav nödvändig del i arbetet med att stärka nätverket mellan Nordiska rådet och EU/EES är att tillsätta en utsänd ämbetsman i Bryssel. Denna person kunde fungera som en neutral antenn som fångar upp vad som är på gång samt sänder informationen vidare till Norden. Den utsände kunde ge "early warnings" till Nordiska rådet samt vara en länk mellan Norden och EU, och kontoret skulle utgöra det nordiska organ som i dag saknas i Bryssel. Den utsände kunde arbeta med att hålla kontakten till politiker, delta på seminarier, ta emot arbetsgrupper samt följa upp aktuella nordiska ämnen. Det är också viktigt att personen regelbundet gör resor till Köpenhamn för att behålla en god kontakt. Det har hur som helst visat sig att åsikterna kring detta förslag går brett isär. Man är dock eniga om att om Nordiska rådet väljer att tillsätta en person i Bryssel så är det oerhört viktigt att hitta en kompetent person som har erfarenheter av både EU/EES och Nordiska rådet sedan tidigare, och att denne har en tjänst på 2-3 år. Erfarenheter visar nämligen att det tar minst ett år att komma in i arbetet ordentligt. Tjänstens längd är av betydelse även ur nätverkshänseende - ett längre mandat ger möjligheter att skapa djupare kontakter. Ett annat alternativ som framförts är att den utsände, likt kommunikationsavdelningen arbetar för både Nordiska rådets sekretariat och Nordiska ministerrådets sekretariat. Detta skulle spara in pengar för bägge parter.

En annan idé är att Nordiska rådet ökar sitt samarbete med de nordiska representanter som finns utsända från de nationella parlamenten i Bryssel. Ett ökat samarbete kunde antingen ta sig uttryck genom att man ser över möjligheterna för Nordiska rådet att dela kontorsutrymmen med de nordiska representanterna i Bryssel och därigenom arbeta mera tillsammans, eller att öka kontakten genom email och regelbundna möten. Väljer man (enligt förslag 14) att inte sända en person till Bryssel, utan istället tillsätta en EU-tjänst på sekretariatet i Köpenhamn, kunde det senare alternativet vara till stor nytta för alla parter.

Fördelar: Förespråkarna pekar på att de allra flesta regioner i Norden sedan länge har ett kontor i Bryssel som bevakar regionens intressen, och att det borde vara självklart också för Nordiska rådet. Ett annat argument är "ambassadörsargumentet"; att den utsände kunde fungera lite som Nordiska rådets ambassadör i Bryssel och vara en del av Nordiska rådets profilering $\mathrm{i}$ EU. Man anser att det är oerhört viktigt att stärka det nordiska varumärket och sätta Nordiska rådet på kartan. Andra 
fördelar med att fysiskt vara på plats är nätverksmöjligheterna, ad hoc-deltagande och de signaler det utsänder.

Nackdelar: Kritikerna är tveksamma till om den utsände verkligen kan ge "valuta för pengarna" och vad arbetsuppgifterna skulle vara. Hur garanterar man en nära kontakt till sekretariatet i Köpenhamn och är det ens möjligt för en person att få en övergripande syn av vad som händer utan att gräva ner sig i oviktiga detaljer? Det gäller att kunna sväva ovanför allt som händer och nyttogöra informationen. Vidare är det dyrt att sända en person till Bryssel, betala kontorsplats, resor och andra kostnader som tillkommer och flera hävdar att det man får ut av en fast tjänst $i$ Bryssel, kan man lika väl få genom mer regelbundna arbetsgruppsresor till Bryssel och Strasbourg.

\section{Förslag 14: att Nordiska rådet ska tillsätta en ny tjänst i sekretariatet i Köpenhamn med huvudansvar på samarbetet med Europeiska unionen och Europaparlamentet}

Ett alternativ till en utsänd person från Nordiska rådet i Bryssel är att tillsätta en "EU-tjänst” på sekretariatet i Köpenhamn. Flera av de intervjuade har efterlyst en person som dagligen arbetar med EU-frågor och således bistår både utskotten och partigrupperna med EU-arbetet. Många anger att den praktiska planeringen av arbetsgruppsresor till Bryssel tar upp väldigt mycket av den ordinarie tiden, vilket skapar stress. "EU-tjänsten" kunde därför dels bestå av praktisk koordinering, dels av liknande uppgifter som den utsände personen i Bryssel skulle ha haft, men kunde även innebära regelbundna resor till Bryssel för att delta i viktiga möten och träffa relevanta personer. Inför varje verksamhetsår kunde personen hjälpa till med EU-prioriteringarna och strategierna, men kunde även jämföra de svenska, finska, åländska och danska direktivspromemoriorna för att se hur man betraktar direktivet i de nordiska länderna. Väljer man att genomföra flera av förslagen i denna rapport tillkommer det även annat som kunde höra till personens arbetsuppgifter. En majoritet av de intervjuade menar att Nordiska rådet behöver en person som arbetar med EU-frågor, men att det med dagens teknik likaväl kan göras från Köpenhamn som från Bryssel. De flesta EU-möten sänds i dag live via webben, vilket möjliggör "ett deltagande" oberoende fysisk plats. Europaparlamentarikerna anser också att det vore bra att ha en kontaktperson i Nordiska rådet. Det är dock ingen nödvändighet att personen är placerad i Köpenhamn. Ett alternativ som framförts är att personen arbetar i det nordiska land som det året har ordförandeklubban i Nordiska rådet, alternativt i det nordiska land som har EU:s ordförandeskap, om så skulle vara fallet.

Fördelar: Det är betydligt billigare att placera personen i sekretariatet i Köpenhamn där det redan finns ett kontor än i Bryssel. Andra fördelar är att man håller en nära kontakt till sekretariatet och utskotten.

Nackdelar: Att tillsätta en ny tjänst är dyrt oberoende var den fysiskt placeras och det krävs strukturering för att få maximalt ut av tjänsten. Man bör koordinera arbetsuppgifterna på ett sätt att de både kompletterar och underlättar utskottens arbete, utan att för den delen ta över dem. Vidare går man miste den unika chans till djupare kontakt och ad hoc-deltagande som man kan få om man fysiskt är på plats i Bryssel. 
Förslag 15: att Nordiska rådet genom sina rekommendationer ska uppmana de nordiska regeringarna att påverka EU:s ministerråd i relevanta EU-frågor

På samma sätt som Nordiska rådet kan ge de nordiska regeringarna rekommendationer kunde man även ge uppmananingar till regeringarna i EU-frågor, med önskan om att de skulle driva en viss fråga i EU:s ministerråd. Detta gäller i första hand Sverige, Finland och Danmark som är medlemmar i EU, men även Norge och Island som är långt förenade genom EES. I rekommendationerna kunde man peka på bristerna i ett direktivförslag samt ge idéer på hur detta kunde lösas.

Fördelar: Rekommendationerna är redan en accepterad och använd metod, som nu bara skulle utvecklas.

Nackdelar: Frågan är hur stor tyngd sådana EU-rekommendationer egentligen skulle ha.

Förslag 16: att Nordiska rådet ska utöka sitt samarbete med parlamentariska organisationer så som Baltisk Församling i syfte att arbeta med för båda, relevanta EU-frågor.

Att stärka nätverket till EU/EES kan göras på andra sätt än genom direkta samarbeten med Europaparlamentet. Man kan även arbeta indirekt genom att stärka nätverket till andra parlamentariska organisationer, för att tillsammans arbeta med EU-frågor som ligger i bägges intresse. Det kan vara genom en dialog om Arktis med The Conference of Parliamentarians of the Arctic Region (CPAR) och EU eller genom en nordisk-baltisk-europeisk diskussion försöka finna konkreta åtgärder för ett renare Östersjön. Och där har samarbetet med Baltisk Församling varit särskilt viktig hittills. Konkret kan ett ökat samarbete till exempel innebära att man arbetar för upprättandet av flera reningsverk i Östersjöregionen eller försöker finna gemensamma smarta lösningar inom energisektorn. Konkreta projektbaserade samarbeten är ledordet enligt de intervjuade, och det ska vara $\mathrm{i}$ frågor som har stor inverkan på de regioner som ingår i samarbetet. I praktiken kan det göras genom att Nordiska rådet och Baltisk Församling intensifierar utbytet av åsikter kring en aktuell EU-fråga, koordinerar aktiviteter eller anordnar gemensamma möten med företrädare för EU.

Fördelar: Ju fler samarbetspartners, desto större möjligheter till påverkan i nordiskt relevanta frågor. Och eftersom Nordiska rådet redan har en god kontakt till den baltiska regionen så är ett ökat samarbete i EU-frågor en naturlig utveckling.

Nackdelar: Precis som med alla samarbeten så krävs en tydlig strategi och konkreta mål för att samarbetet ska ge mervärde.

Förslag 17: att Nordiska rådet ska utöka sitt samarbete med parlamentariska organisationer så som Benelux-unionen i syfte att tillsammans arbeta med för båda, relevanta EU-frågor.

Benelux-unionen (Belgien, Nederländerna och Luxemburg) är i likhet med Nordiska rådet, ett parlamentariskt samarbete mellan flera länder där man arbetar med frågor av gemensamt intresse. Nordiska rådet har sedan tidigare kontakter med Benelux och representanter därifrån brukar årligen 
delta i Nordiska rådets session. De två gemenskaperna kunde emellertid utöka sitt samarbete för att arbeta med EU-frågor som är av intresse för båda parter. Det kan göras genom att båda redogör för sina EU-prioriteringar och sedan väljer en eller två saker som båda parter ser en nytta i att arbeta med. Potentiella samarbetsområden som nämnts är energi och miljö.

På motsvarande sätt kan samarbetet med Visegrad-länderna, som påbörjades 2013, utvecklas till att också få en EU-dimension. Nordiska rådet har också lösare kontakter till andra regionala, parlamentariska organisationer som British Irish Parliamentary Assembly, där EU-frågor kan komma på dagordningen.

Fördelar: Benelux-unionens sekretariat är fysiskt placerat i Bryssel, vilket kan vara bra vid praktiska arrangemang. Dessutom hävdar flera att de norra och centraleuropeiska länderna i många avseenden har liknande grundvärderingar, vilket gör det relativt lätt att hitta gemensamma sakfrågor att driva.

Nackdelar: Det finns vissa skillnader i ländernas relation till EU som kan vara utmanande; alla länder i Benelux och Visegrad är medlemmar i EU, men det är inte alla nordiska länder. Detta behöver emellertid inte vara ett hinder för samarbete.

\section{Förslag 18: att Nordiska rådet ska utöka sin kontakt med de nordiska ständiga representationerna i Bryssel}

Den svenska, finska och danska representationen har samtliga en eller två personer, vars huvudsakliga arbetsuppgifter är att ansvara för relationerna till Europaparlamentet och löpande hålla kontakten med landets Europaparlamentariker. De utbyter därför regelbundet information för att få en uppfattning om hur tongångarna i respektive institutioner går. Förutom samarbetet med parlamentet har de ständiga representationerna även kontakt med kommissionen och nationella regionkontor. De deltar oftast i plenumveckan i Strasbourg där de kan möta sina motsvarigheter från andra ständiga representationer. Likt andra aktörer i Bryssel har de ständiga representationerna ett behov av ett brett nätverk och en samverkan med Nordiska rådet kunde således vara till fördel för bägge parter. Från Nordiska rådets sida är det flera som menar att ett starkare nätverk till de nordiska representationerna, regionkontoren, Europaparlamentarikerna och lobbyorganisationer är ett alternativ till att ha en utsänd person i Bryssel.

Fördelar: De ständiga representationerna är en värdefull kanal dels till ministerrådet, dels till de nationella regeringarna. De hanterar många juridiska detaljfrågor kring direktiven, vilket kan vara till hjälp om Nordiska rådet någon gång vill ge konkreta ändringsförslag till de nordiska Europaparlamentarikerna eller kommissionen. En fördel är även att de är på plats i Bryssel och har rätt så goda resurser.

Nackdelar: Eftersom de ständiga representationerna arbetar för de nationella regeringarna och Nordiska rådets medlemmar delvis kommer från oppositionspartierna i de nationella parlamenten är ett helt fritt informationsutbyte knappast möjligt.

Förslag 19: att Nordiska rådet ska utöka sin kontakt med de nordiska regionkontoren i Bryssel 
Oavsett om man tillsätter en EU-utsänd i Bryssel eller inte så finns det en uppfattning bland de intervjuade, att Nordiska rådet $\mathrm{i}$ högre grad borde arbeta med de aktörer som redan finns på plats $\mathrm{i}$ Bryssel. Med det menar man att Nordiska rådet borde utöka sitt samarbete inte bara med de nordiska Europaparlamentarikerna och de nordiska ständiga representationerna, utan även med de nordiska regionkontoren. I Bryssel finns det i dagsläget tolv svenska, sex norska, sex finska, fem danska och ett isländskt regionkontor, vars huvudsakliga syfte är att vara "regionens förlängda arm" och bevaka regionala intressen på EU-nivå. Därutöver har Färöarna, Grönland och Åland representanter i Bryssel. Det är emellertid stora skillnader mellan regionkontorens organisation och arbetsuppgifter; vissa jobbar mera projektbaserat, andra löpande med utvalda politikområden. Vissa finansieras av en lokal huvudman, andra av många olika. En del har mer informativ verksamhet, andra försöker påverka i olika policyfrågor. En uppfattning bland regionkontoren är dock att det sker en kraftig regionalisering i Bryssel som gör makroregioner så som Norden allt mer inflytelserika och att det blir allt lättare att göra sin regionala röst hörd på den europeiska arenan. Men det gäller även för regioner av mindre storlek än Norden. Kommissionen är lyhörd i sin ambition om att föra EU ner på gräsrotsnivå, och tar sig ofta tid till att träffa regionkontoren för enskilda möten. Men regionkontoren arbetar inte bara mot kommissionen, parlamentet anses också användbart då man vill marknadsföra eller föra fram regionala intressen eller få kontakt med en viss Europaparlamentariker. Vidare deltar regionkontoren i många regionala forum och samarbetsprogram i konkreta sakfrågor, vilket betraktas som en oerhörd viktig del av verksamheten. De anser att en fysisk närvaro i Bryssel är grundläggande för att i god tid kunna framföra sina ståndpunkter till kommissionen, men de håller även en tät kontakt med sin region genom att resa hem varannan eller var tredje vecka. Det är viktigt för att få information om vad som är aktuellt på hemmaplan.

Som ensam aktör i Bryssel kommer man inte långt. Chansen att få möten med viktiga personer ökar om man är flera som går samman och ur ett ekonomiskt perspektiv är det bättre att ha många samarbetspartners då resurserna alltid är begränsade. De flesta av regionkontoren är ganska små och har mellan 1-6 anställda, ofta med praktikanter, men flera har framhållit att storleken inte är av så stor betydelse om man har ett brett nätverk och goda idéer. Ett första steg för Nordiska rådet är att göra en lista på vilka regionkontor som arbetar med vilka frågor och sedan att ta kontakt och bygga upp djupare relationer. Tillsammans kan man sedan arrangera seminarier eller möten med nordiska Europaparlamentariker i frågor av gemensamt intresse. Målet borde vara att träffa något regionkontor vid varje resa till Bryssel, alternativt genom sin EU-utsände skapa samarbetsvägar.

Fördelar: Regionkontoren och Nordiska rådet har många likartade intressen i EU; man vill bevaka regionala nordiska intressen, skapa kontakter, få information samt finna vägar för att göra sin röst hörd. Många av regionkontoren har funnits länge i Bryssel och har mycket kunskap och erfarenheter, vilket Nordiska rådet borde dra fördel av. Genom regionkontoren kan Nordiska rådet även få fler kanaler till kommissionen.

Nackdelar: Det är ett gediget arbete att bygga upp och upprätthålla djupare relationer. 
Förslag 20: att Nordiska rådet $i$ högre grad ska använda sig av sociala medier i syftet att stärka kontakten till de nordiska Europaparlamentarikerna

En stor del av informationsutbytet, viljeyttringarna och påtryckningsförsöken i samhällsfrågor sker i dag genom sociala medier så som Facebook och de flesta personer är flitiga internetanvändare. Flera av de intervjuade har därför lyft fram sociala meder som en användbar metod för att hålla kontakten med de nordiska Europaparlamentarikerna. Det kunde till exempel göras genom en gemensam Facebook-grupp, som kunde fungera som en informell portal mellan politiker och tjänstemän i Nordiska rådet och i Europaparlamentet. Där kunde man ställa frågor till varandra samt dela med sig av information och aktuella nyheter från EU och Norden.

Fördelar: En Facebook-grupp är en gratis, informell och enkel metod för att upprätthålla kontakten. Det krävs inte mycket tid från användaren och når ut till alla relevanta personer.

Nackdelar: Utmaningen med detta förslag är dels att en person ska vara ansvarig för att skapa och granska sidan, dels att den ständigt bör uppdateras och hållas aktuellt. Det är även troligt att diskussionerna hålls på en ganska ytlig nivå eftersom politiker från alla partier är med.

\section{Förslag 21: att Nordiska rådet ska be om att få delta i EuroNest-möten i syfte att öka samarbetet kring Det Östra Partnerskapet}

EuroNest Parlamentariska Församling grundades 2011 och är ett parlamentariskt forum med målet att främja politiskt associering och ekonomisk integration mellan EU och det Östliga Partnerskapet. Alla möten är öppna att delta i och förutom Europaparlamentet är också Azerbajdzjan, Armenien, Moldavien, Georgien och Ukraina medlemmar. Vitryssland var tidigare medlem men uteslöts efter valet 2010 på grund av det politiska läget i landet. EuroNests plenarmöte äger rum en gång per år i Bryssel eller i ett av de östeuropeiska länderna och därutöver har varje utskott två utskottsmöten i året. Plenarmötet sänds live via webben. De fyra olika utskotten är: Committee on Political Affairs, Human Rights and Democracy; Committee on Economic Integration, Legal Approximation and Convergence with EU Policies; Committee on Energy Security och Committee on Social Affairs, Education, Culture and Civil Society. Nordiska rådet har redan olika samarbetspartners i Östeuropa, men om det finns intresse för ett utvidgat nätverk så kan EuroNest vara användbar. Förslaget är således att Nordiska rådets presidium som har det internationella ansvaret, ska be om att få delta $\mathrm{i}$ EuroNests möten då det behandlas intressanta frågor. Vill man hitta en samarbetsform som är specifikt inriktad på Vitryssland, kan man pröva ta kontakt med de nordiska Europaparlamentariker som sitter i Delegationen för relationerna med Vitryssland. Deras möten är dock inte offentliga.

Fördelar: Detta förslag öppnar dörren för nya samarbeten och skapar en dialog med Europaparlamentet om det Östliga Partnerskapet och Vitryssland.

Nackdelar: Nordiska rådet har inte arbetat mot medlemsländerna i EuroNest tidigare, vilket betyder att detta är helt nya kontakter. Vidare kan Vitryssland vara svår att nå, också genom denna kanal.

\subsection{EU i utskottsarbetet}


EU-arbetet i de fem olika fackutskotten i Nordiska rådet är väldigt varierande. Vissa av utskotten har haft fler resor till Bryssel än andra och arbetsmetoderna har även de sett olika ut. Många av de intervjuade anser ändå att det är genom utskotten och de specifika sakfrågorna som det finns bäst möjligheter att stärka sitt nätverk till Europaparlamentet. Sakfrågorna anses vara konkreta ingångsportar som dessutom är bestående när politikerna med jämna mellanrum byts ut. När Nordiska rådet får kännedom om ett nytt EU-direktiv som det finns en nordisk nytta att arbeta med, så är det alltså genom utskotten många anser att man ska agera. Eftersom det är presidiet som ansvarar för den internationella verksamheten så är det viktigt att utskotten alltid går via presidiet vid sådan kontakt. Här nedan följer således förslag på hur Nordiska rådet, genom sina utskott kan arbeta för att stärka sitt samarbete med EU/EES.

Förslag 22: att Nordiska rådets utskott genom Europeiska kommissionens grön- och vitböcker även fortsättningsvis ska ge utlåtanden om ny EU-lagstiftning i frågor av nordisk relevans

Nordiska rådet kan, liksom många andra aktörer, ge sitt utlåtande om ny EU-lagstiftning genom kommissionens grön- och vitböcker och har även gjort så i frågor av nordisk relevans. På 2013-års sommarmöte till exempel, vidtog Nordiska rådets miljö- och naturresursutskott ett utlåtande om grönboken om ramen för energi- och klimatpolitiken 2030 och sände det till EU-kommissionen. Man bör således fortsätta med det i frågor som har en nordisk nytta, för att göra det till en del av det löpande arbetet. Erfarenheter visar dock att man bör ha stor detaljkunskap i ämnet för att synpunkterna ska ha en reell effekt och för att man ska kunna påverka. Allt för generella ståndpunkter tenderar tyvärr att falla mellan stolarna.

Fördelar: Det är den enda formella kanalen Nordiska rådet har till kommissionen och är därför oerhört viktig.

Nackdelar: Det är en ambitiös och tidskrävande metod som kräver mycket kunskap i ämnet.

Förslag 23: att Nordiska rådets utskott i högre grad ska överväga möjligheterna att sända representanter till Bryssel eller Strasbourg för att delta $i$, eller själva arrangera seminarier, hearings eller möten om en specifik sakfråga

Det är en avsevärt högre tröskel att ta kontakt om man aldrig har träffats fysiskt och ur ett nätverkshänseende är det därför betydligt bättre att mötas öga-mot-öga först. Sett ur det avseendet är seminarier, hearings, konferenser eller rundabordssamtal väldigt viktiga och ger dessutom möjligheten att tillskaffa eller dela med sig av information och åsikter. Representanter från Nordiska rådets utskott kunde därför själva, tillsammans med en nordisk Europaparlamentariker eller med något av de nordiska regionkontoren i Bryssel mer regelbundet delta $\mathrm{i}$, eller arrangera sådana möten i Bryssel eller Strasbourg. När man väl har fătt en god kontakt med en Europaparlamentariker så är det en välfungerande ingång till hela parlamentet. Många varnar dock Nordiska rådet för att börja konkurrera med den ofantliga mängd lobbyister som redan finns $i$ Bryssel och bli en del av "lobbyistkåren". Det utgör dock inget hinder för Nordiska rådet att emellanåt ge Europaparlamentarikerna konkreta ändringsförslag till olika direktiv. 
Väl i Bryssel finns det flera metoder man kan använda för att öka samarbetet. Av praktiska skäl så som tillgång till mötesrum i parlamentet är det enklast att arrangera seminarier tillsammans med en Europaparlamentariker. Man kan även anordna ett frukostmöte där man bjuder in relevanta personer för att diskutera en fråga. Här kan man till exempel samarbeta med något av de nordiska regionkontoren i Bryssel som är vana vid att arrangera sådana slags möten. För att få maximalt ut av varje resa bör det finnas en hög konkretiseringsnivå som har diskuterats på förhand. Vilket syfte har resan, vilka mål finns det och hur ska detta bäst uppnås under resans gång? Flera upplever att det är något som ibland har saknats. Man bör också ha som målsättning att alltid ha en eller flera politiker med på resorna, eftersom det har visat sig vara enklare att få till ett möte med en annan politiker då. Vad gäller antalet deltagare så anser många att ett mindre antal är mer ändamålsenligt än ett större. För att dra ner på kostnaderna är ett alternativ att man arrangerar mötet tillsammans med Nordiska ministerrådet. Det gjordes senast i februari 2013 då Nordiska rådets miljöutskott ordnade en öppen konferens om One Health-direktivet i Bryssel tillsammans med Nordiska ministerrådet.

Vad gäller den fysiska platsen så finns det många fördelar med Bryssel framom Strasbourg; det är lättare att få till ett möte med Europaparlamentarikerna eftersom de i allmänhet är mindre uppbokade än i Strasbourg och dessutom finns de nordiska regionkontoren och de ständiga representationerna på plats i Bryssel, vilket gör ett samarbete möjligt. I Bryssel kan det dock vara svårt att hitta ett mötestillfälle som passar alla. I Strasbourg däremot, samlas alla Europaparlamentariker på samma ställe hela veckan, vilket ger möjligheter till gemensamma möten. Ett exempel på Strasbourg som lyckad mötesplats var när Rederierna i Finland önskade påverka $i$ svaveldirektivet och arrangerade ett möte med de nordiska Europaparlamentarikerna där. Det var en god uppslutning och föreningen kunde framgångsrikt framföra sina åsikter. Det är dock ett faktum att plenumveckorna i Strasbourg är Europaparlamentarikernas mest hektiska veckor och det är inte alls en självklarhet att de har tid att träffas. Dessutom är reseförbindelserna från Norden till Strasbourg mer besvärliga än till Bryssel.

Fördelar: På arbetsgruppsresor, seminarier och konferenser lär man sig mycket om det aktuella ämnet och knyter värdefulla kontakter. Dessutom ger det Nordiska rådet mer synlighet, vilket stärker det nordiska varumärket i Europa.

Nackdelar: Mer regelbundna arbetsgruppsresor till Bryssel eller Strasbourg är dyrt eftersom man behöver såväl transport som logi och resan snabbast kan göras på två arbetsdagar. Det krävs mycket koordinering och planering innan resan och mervärdet är i många avseenden avhängigt på personerna som möts.

Förslag 24: att Nordiska rådets utskott ska be om att få delta som observatörer vid Konferensen mellan de parlamentariska organen för EU-frågor vid Europeiska unionens parlament (COSAC) samt vid ordförandeskapsmöten då relevanta frågor tas upp på dagordningen

COSAC, eller Konferensen mellan de parlamentariska organen för EU-frågor vid Europeiska Unionens parlament (The Conference of Parliamentary Committees for Union Affairs), är mellanstatliga möten som arrangeras av och i ordförandeskapslandet två gånger om året. Då deltar 
ordförandena, eller medlemmar, från de nationella EU-utskotten. Syftet med COSAC är att skapa ett forum där man regelbundet kan diskutera aktuella frågor samt främja utbytet av information och bästa praxis mellan de nationella parlamenten och Europaparlamentet, samt mellan dess utskott. Besluten är inte bindande för parlamenten, utan kan betraktas som rekommendationer. Deltagare på konferensen är delegationer om max sex personer från varje nationellt medlemsparlament, sex ledamöter från Europaparlamentet och speciellt inbjudna observatörer.

Utöver COSAC-mötena arrangeras även ett ordförandeskapsmöte varje halvår i ett specifikt ämne. De senaste i raden var ett möte i Dublin under det irländska ordförandeskapet på våren 2013 och ett i Vilnius under det litauiska ordförandeskapet under andra halvan av 2013, bägge med EU:s jordbrukspolitik som tema. Nordiska rådets miljö-och naturresursutskott bad då om invitation och fick även möjlighet att tala. Man uttryckte den nordiska ståndpunkten samtidigt som man synliggjorde Norden. Samma utskott deltog även i ett av ordförandeskapets ad hoc möten om makroregionala strategier och miljöskydd i november 2013, där ordförandena från de nationella parlamentens miljöutskott och utskottet för statsadministration och lokal förvaltning deltog. Då framfördes Nordiska rådets ståndpunkter samt några nordiska erfarenheter. Nordiska rådet har alltså deltagit som observatör vid dessa möten, men skulle enligt detta förslag mer regelbundet be om att få delta, då nordiskt relevanta frågor tas upp på dagordningen.

Fördelar: COSAC och ordförandeskapsmötena är en formell kanal för Nordiska rådet till de nationella medlemsparlamenten och Europaparlamentet. Man kan knyta kontakter, inte bara till nordiska, utan även till andra parlamentariker, men även föra fram en nordisk ståndpunkt. Mötena är goda informationskällor där man kan få kännedom om hur tongångarna går i medlemsländernas parlament.

Nackdelar: Det är inte självklart att Nordiska rådet făr delta vid COSAC-mötena, - det är upp till ordförandeskapet i samråd med trojkan att invitera speciella gäster. Dessutom har COSAC-mötenas betydelse och relevans ifrågasatts en del på senaste tiden och kallats "ett diskussionsforum utan någon egentlig makt". Kritik har även riktats mot både längden på COSAC och storleken på delegationerna. Många anser att två och en halv dag är för lång tid och att nätverkandet hämmas då det är så många deltagare.

Förslag 25: att Nordiska rådets utskott ska be om att få delta som observatörer vid de Interparlamentariska utskottsmötena organiserade av Europaparlamentets utskott, då relevanta frågor tas upp på dagordningen

De interparlamentariska utskottsmötena (Interparliamentary Committee Meetings) i Bryssel är mötena mellan de nationella medlemsparlamentens utskott och Europaparlamentets olika utskott. En till två gånger i året, utöver COSAC-mötena som nämndes ovan, bjuder Europaparlamentsutskotten in såväl politiker som tjänstemän från de nationella parlamentens motsvarande fackutskott för att diskutera en aktuell fråga eller EU-lagstiftning. Förutom utskottsrepresentanterna kan även delegationer från icke-medlemsländer och organisationer delta. Som exempel kan sägas att både det schweiziska parlamentet, norska parlamentet och Arktiska rådet har deltagit då det funnits intressanta punkter på dagordningen och hösten 2012 deltog även 
Nordiska rådet i ett möte om fiskeripolitik. Utöver dessa är även kommissionen samt en mängd Europaparlamentariker och assistenter på plats. Förslaget är att Nordiska rådet mer regelbundet ska be utskottssekretariaten i Europaparlamentet om invitation till dessa möten, då det behandlas en fråga av nordiskt intresse. Mötena är vanligtvis halvdagsmöten, de är offentliga, sänds ofta live via webben och tolkas till alla medlemsländers språk.

Utöver detta arrangerar ordförandeskapslandet ofta möten i relevanta teman under året. Det är då upp till ordförandeskapslandet och ansvarigt utskott i Europaparlamentet att bestämma vilka de bjuder in.

Fördelar: Ett plus med de interparlamentariska mötena är att det redan är en inarbetad och institutionaliserad samarbetsform. De ger nya infallsvinklar och information från medlemsländernas parlament om hur de ser på saken. Nordiska rådet har även möjlighet att i ett tal dela med sig av sina åsikter samt "best practices". Det är också ett mycket bra forum för nätverksbyggande.

Nackdelar: Mötena riktar sig huvudsakligen till medlemsländernas parlament, så det är ingen självklarhet att få delta. Om man får en invitation ligger ett stort ansvar på deltagaren att vara aktiv och påläst för att mötet ska ge mervärde. Dessutom har mötena ifrågasatts då man inte fattar några bindande beslut.

\section{Förslag 26: att Nordiska rådets utskott ska be om att få delta på någon av de nordisk-baltiska frukostarna i Strasbourg}

Det är inte bara i Bryssel som det lönar sig att vara på plats, också i Strasbourg finns värdefulla möjligheter att skapa nätverk, inhämta information och påverka. Den nordisk-baltiska frukosten koordineras för närvarande av Europaparlamentariker Kent Johansson och är ett återkommande frukostmöte under plenumveckan i Strasbourg där olika frågor av nordisk relevans behandlas. Det rätt så informella mötet hålls i en restaurang, dit olika talare bjuds in. Vill man påverka i de saker som tas upp till omröstning i Strasbourg så är det här ett allt för sent tillfälle, men man kan däremot diskutera andra aktuella frågor med parlamentarikerna. Presidiets EU-rapportör Bertel Haarder deltog i ett sådant möte $\mathrm{i}$ juni 2012, men i framtiden kan det vara nyttigt med mer regelbundet deltagande.

Fördelar: Det är ett utmärkt nätverkstillfälle då såväl nordiska som baltiska Europaparlamentariker, assistenter, ämbetsmän från de nordiska ständiga representationerna i Bryssel och ibland någon av de nordiska parlamentens utsända ämbetsmän i Bryssel brukar delta.

Nackdelar: Förutom den ovannämnda gruppen så deltar även en del journalister, vilket gör att diskussionerna i viss mån kan vara försiktiga.

Förslag 27: att Nordiska rådets utskott i högre grad ska skapa och upprätthålla kontakter till nordiska Europaparlamentariker och tjänstemän i motsvarande Europaparlamentsutskott

Goda och regelbundna kontakter till Europaparlamentet är enligt de intervjuade a och o för att Nordiska rådet ska kunna påverka i EU och flera efterlyser ett mer standardiserat flöde av 
information och bevakning. Och en stärkt kontakt handlar ju i första hand om att bygga upp mänskliga kontakter, vilket i detta fall är att få till stånd ett tätare samarbete med de nordiska Europaparlamentarikerna. Den vanligaste påverkningsmetoden som lobbyister och andra intresseorganisationer använder är att ta kontakt med de parlamentariker som sitter i det utskott där ett specifikt direktiv behandlas och sedan efter hand be om ett möte för att diskutera frågan. Lobbyisterna brukar även skicka konkreta ändringsförslag eller be parlamentarikern att delta $\mathrm{i}$ ett seminarium de arrangerar. Detta kunde Nordiska rådet också göra. Ett tätare samarbete gynnar även de nordiska Europaparlamentarikerna, som får en kanal att påverka de nordiska parlamenten.

Denna metod kan tillämpas också på tjänstemannanivå. Nordiska rådets sekretariat kan vid arbetsgruppsresor till Bryssel be om ett möte med en tjänsteman från sekretariatet i ett Europaparlamentsutskott eller med en politisk assistent. Dessa kontakter är viktiga att ha i det löpande arbetet.

Fördelar: När man väl har byggt upp en god relation med en Europaparlamentariker är det en ingång till hela parlamentet samt en källa till information. Det finns även många fördelar med att på tjänstemannanivå skapa kontakter till utskottssekretariaten och Europaparlamentarikernas assistenter eftersom de inte byts ut lika ofta som politikerna. Viktigt att notera är även att assistenterna i Europaparlamentet i allmänhet har betydligt större ansvar än de har på nationellt.

Nackdelar: Det finns en stor politisk blandning i Nordiska rådets utskott och för att kunna driva igenom något så krävs det att en majoritet, utan hänsyn till partitillhörighet, stöder förslaget. Man måste sedan finna de politiker i Europaparlamentsutskotten som har likadana ståndpunkter som Nordiska rådets utskott och försöka påverka genom honom eller henne. Det kan dock finnas svårigheter med att få fram en gemensam ståndpunkt i utskottet. Det andra alternativet, att på tjänstemannanivå ta kontakt med utskottssekretariaten i Europaparlamentet, är en betydligt mer formell väg att gå. Det har även visat sig att det bör finnas en mycket hög konkretiseringsnivå för att utskottssekretariaten i Europaparlamentet ska vara intresserade av att ha kontakt.

\subsection{EU i partigruppsarbetet}

Såväl Nordiska rådets medlemmar som Europaparlamentet består av politiker som valt olika politiska grupper baserat på sina åsikter och samhällssyn, och särskilt i Europaparlamentet är partigrupperna av mycket stor betydelse. Flera menar därför att det är partigruppsvägen som är den mest naturliga när man vill stärka nätverket och där man har störst chans att skapa goda kontakter och göra sin röst hörd. Här följer förslag på hur man genom Nordiska rådets partigrupper kan arbeta för att stärka samarbetet till EU/EES.

Förslag 28: att Nordiska rådets partigrupper ska arbeta för att öka kontakten med Europaparlamentets partigrupper både på politisk- och tjänstemannanivå

Ett tätare samarbete mellan de nordiska Europaparlamentarikerna i de olika partigrupperna och Nordiska rådets partigrupper kan konkret göras genom att en nationell parlamentariker tar kontakt med en Europaparlamentariker av samma partifärg. Enklaste sättet att hålla kontakten är genom e- 
post, telefonsamtal eller avtala om ett möte sinsemellan. Men en ökad kontakt kan även ta sig uttryck i att de nordiska partigrupperna regelbundet skulle bjuda in sina europeiska ledamöter till sina möten. I intervjuerna anger flera nordiska Europaparlamentariker att de gärna tar del av statistik, fakta eller data från Nordiska rådet, vilket Nordiska rådets partigrupper alltså kan använda för att komma i kontakt. Och ju mer detaljerad man är när man försöker påverka, desto bättre resultat.

En ökad kontakt partigruppsvis kan även ske på tjänstemannanivå genom att Nordiska rådets partigruppssekreterare kontaktar Europaparlamentets partigruppssekretariat. Ett lyckat exempel på en sådan kontakt var när Mittengruppen i Nordiska rådet, genom sin generalsekreterare tog kontakt med Europaparlamentets liberala grupp (ALDE) och sedan gjorde ett studiebesök hos dem i Bryssel år 2011. Nätverket förstärktes ytterligare när dem året efter, tillsammans med ALDE arrangerade ett seminarium för internationella gäster i samband med det finska Centerpartiets årsmöte i juni 2012.

Fördelar: Samarbetet kan vara lättare då kontakten sker på ett politiskt plan. Det kan även leda till ett ökat samarbete mellan nordiska Europaparlamentariker inom samma partigrupp, vilket tidigare erfarenheter visat sig vara lyckat. En Europaparlamentariker berättar att hon just tack vare en sådan samverkan lyckades medverka till att Sverige får behålla sina 20 mandat inför nästa Europaparlamentsval. Fördelarna med att arbeta genom Nordiska rådets partigrupper är även att det är större chans att få fram mer detaljerade ståndpunkter än genom utskotten. Samarbete över partigränserna är en utmaning och tenderar lätt att resultera i alltför generella ståndpunkter.

Nackdelar: Erfarenheter visar att det kan vara besvärligt att ta kontakt med Europaparlamentets partigruppssekretariat. Det ställer krav på Nordiska rådets partigrupper att finna frågor där man har en gemensam ståndpunkt, så att diskussionen kan hållas på en så konkret nivå som möjligt. En annan svårighet är den politiska indelningen; ett parti som tillhör en grupp i Norden, kan tillhöra en annan i Europa.

\section{Avslutning}

Nordiska rådets strävan mot att stärka samarbetet med EU är inget nytt. Under de senaste åren har man gjort flera försök att göra EU-frågorna mer integrerade i det löpande arbetet. Men unionens lagstiftningsområden växer hela tiden och det finns därför en allt större anledning att rikta blickarna söderut för att $\mathrm{i}$ god tid kunna påverka lagstiftningen och således motverka att problem, så som gränshinder senare uppdagas. Men att påverka är inte bara att säga nej, ett ökat inflytande ger också möjligheten att tillsammans uppmuntra till viktiga beslut. Till skillnad från Nordiska ministerrådet som genom de nordiska regeringarna arbetar mot Europeiska ministerrådet, är Nordiska rådets naturliga ingång till EU genom Europaparlamentet - och det finns mycket att vinna. Ett stärkt nätverk mellan Nordiska rådet och de nordiska Europaparlamentarikerna kan bidra till ett större inflytande för Norden i EU, ett tätare informationsflöde samt ökade chanser till bättre politiska poster för de nordiska Europaparlamentarikerna då de arbetar mera ihop.

Målen är många, men vilka medel som ska användas för att stärka samarbetet finns det delade åsikter om. En del tycker att det ska ske genom formella former och officiella kontakter, medan 
andra förespråkar mer informellt och ad hoc-deltagande då det behövs. Den bästa vägen är kanske någonstans där mitt emellan. I den här rapporten har det i fyra olika delar presenterats förslag på hur Nordiska rådet - genom utbildning och information, genom struktureringar i den löpande verksamheten, i utskottsarbetet samt i partigrupperna - kan stärka sitt nätverk till EU/EES. Som grund för förslagen finns 62 intervjuer som har gjorts med nordiska politiker och tjänstemän $i$ Norden och EU, representanter från nordiska regionkontor och ständiga representationer samt med andra relevanta personer inom det nordiska nätverket, och där har flera viktiga tendenser kommit fram.

I takt med att unionen växer och allt mer makt tillfaller EU, syns även en utveckling där regionala samarbeten får allt mer betydelse. Det märker man inte minst genom den stora mängd regionkontor och regionala nätverk som finns i Bryssel. Nordisk närvaro i Bryssel bedöms därför bli allt viktigare om man vill vara med och påverka och många anser att Nordiska rådet borde tillsätta en person som arbetar med EU-frågor på heltid. Var denna person ska vara placerad är man dock oeniga om. En del önskar en permanent person i Bryssel, andra på sekretariatet i Köpenhamn, medan en tredje grupp menar att resurserna bättre kan användas på att mer regelbundet delta i möten i Bryssel och Strasbourg. Något alla är eniga om är dock att Nordiska rådet allt oftare bör försöka nå konsensus åtminstone till vissa delar - i de frågor man vill påverka och därefter framföra det till olika aktörer på plats. Vidare bör Nordiska rådet öka sin kunskap om EU, få en tätare kontakt med de nordiska Europaparlamentarikerna, öka utbytet av information mellan Nordiska rådet och andra aktörer i Bryssel, öka koordineringen av EU-frågor mellan de nordiska parlamenten samt ett få till stånd ett mer systematiserat EU-arbete på Nordiska rådets sekretariat i Köpenhamn. Man bör av kostnadsskäl basera EU-arbetet på redan existerande resurser och därför skapa goda kontakter till de aktörer som redan finns på plats i Bryssel.

En annan viktig aspekt är marknadsföringen av det nordiska varumärket, så att Nordiska rådet blir välkänt också utanför Norden. I dag är tyvärr det nordiska samarbetet rätt så okänt i Europa, men genom ett flitigt deltagande i möten kan Nordiska rådet visa att de faktiskt är en aktör värd att lyssna på. Det är flera som har föreslagit att man kunde använda den nordiska kulturen som en del i marknadsföringen, till exempel i samband med konferenser. Även om flertalet är positiva till Nordiska rådets EU-satsning så finns det även en grupp som är lite mer bekymrade och kritiska. Orosmoln som framförts är att arbetsbördan blir mycket större och man understryker därför att ledordet bör vara kvalitet framom kvantitet. Man har svårt att se att Nordiska rådet skulle kunna få något inflytande eller att den nordiska stämman skulle ljuda högre än alla de andra rösterna $\mathrm{i}$ Europa. Vidare är man skeptisk till att de nordiska länderna finner frågor som de kan nå konsensus i. Det är oerhört viktigt att man ett tag efter man har vidtagit åtgärder utvärderar hur de fungerar och om man eventuellt kan göra några ändringar för att nå ett bättre resultat. Kanske kommer man fram till att vissa åtgärder inte alls hade den effekt man önskade och får då lov att avsluta dem. Därutöver understryker många att det är väldigt viktigt att hålla en tät dialog med presidiet $\mathrm{i}$ all internationell kontakt som förs. 
Allmäntaget visar dock intervjuerna att en stor majoritet är positivt inställda till att öka kontakten till EU, men anger att det är svårt att ta de första stegen och att hitta användbara verktyg. Genom åtgärderna som integrerar EU-arbetet i Nordiska rådets löpande arbete (del 3.2.) kan det förhoppningsvis lösas. En politiker hävdar att det är de formella vägarna som skapar de informella. Utan "krav" på formell kontakt är det svårt att få till de spontana och personliga kontakterna. Det är en utmaning att sätta nordiskt fotavtryck i europeisk politik och det är svårt att avgöra om man gör avtryck och vilken nyttan är av insatserna. Flera har dock understrukit att resultaten i många avseenden är beroende av den politiska viljan och att den mentala nivån därför är fundamental $\mathrm{i}$ denna process. Det är 19 år sedan Sverige och Finland gick med i EU och 41 år sedan Danmark anslöt sig till unionen, och det är nu många som anser att man borde ha kommit till en punkt då ett ökat samarbete faktiskt är högt prioriterat. Man bör putsa bort föreställningen om att EU är en gigantisk, problematisk och byråkratisk maskin som inte går att påverka. Det europeiska samarbetet drivs liksom det nordiska, av individer och just därför är kontakterna och nätverken såväl målet som medlen i denna rapport. I maj 2014 är det dags för Europaparlamentsval och det kan vara startpunkten, inte bara för de nyinvalda parlamentarikerna, utan även för Nordiska rådets resa mot Europa.

\section{Källförteckning samt lista på de intervjuade Bibliography and the list of the interviewees}

Etzold, Tobias. International Peace Institute. "The Case of the Nordic Councils: Mapping Multilateralism in Transition No. 1”. New York: 2013.

Europeiska unionens hemsida: www.europa.eu. (3.10-2013).

Hemsidan för Europaparlamentets relationer med de nationella parlamenten: http://www.europarl.europa.eu/webnp/cms/pid/3. (15.11-2013).

Nordiska rådets hemsida: http://www.norden.org/sv/nordiska-raadet. (5.11-2013).

Svenska riksdagens EU-upplysning: http://www.eu-upplysningen.se/Sverige-i-EU/EU-lagar-gallerframfor-svenska-lagar/. (15.11-2013).

Presidieförslag om Nordiska rådets EU-strategi: ”En nordisk stämma i EU”, A 1535/presidiet.

Tiilikainen, Teija \& Korhonen, Kaisa. Utrikespolitiska institutet i Finland. "Norden - Making a Difference? Possibilities for enhanced Nordic cooperation in international affairs. The Norden 2020 project report”. Helsingfors: FIIA report, 2011.

Följande 62 personer har intervjuats till denna rapport. I undantagsfall har frågor ställts genom e-post: 
The following 62 persons have been interviewed to this report. The questions have been asked by e-mail in a few cases:

Nordiska Europaparlamentariker/ Nordic members of the European Parliament:

Anna Hedh
Anne E. Jensen
Anneli Jäätteenmäki
Cecilia Wikström
Christel Schaldemose
Christian Engström
Isabella Lövin
Kent Johansson
Margrete Auken
Marit Paulsen
Marita Ulvskog
Morten Løkkegaard
Nils Thorvalds
Olle Schmidt
Sampo Terho
Søren Søndergaard

Sverige

Danmark

Finland

Sverige

Danmark

Sverige

Sverige

Sverige

Danmark

Sverige

Sverige

Danmark

Finland

Sverige

Finland

Danmark
S\&D

ALDE

ALDE

ALDE

S\&D

Greens/EFA

Greens/EFA

ALDE

Greens/EFA

ALDE

S\&D

ALDE

ALDE

ALDE

EFD

GUE/NGL

Medlemmar i Nordiska rådet/ Members of the Nordic Council:

Anders Eriksson

Annicka Engblom

Ann-Kristine Johansson

Arto Pirttilahti

Bertel Haarder

Cecilie Tenfjord-Toftby

Christina Gestrin

Finn Sørensen

Göran Montan

Henrik Dam Christensen

Høgni Hoydal

Karin Åström

Kimmo Sasi

Marit Nybakk

Steingrimur J. Sigfusson

Wille Valve
Åland

Sverige

Sverige

Finland

Danmark

Sverige

Finland

Danmark

Sverige

Danmark

Färöarna

Sverige

Finland

Norge

Island

Åland
Mittengruppen

Konservativa gruppen

Socialdemokratiska gruppen

Mittengruppen

Mittengruppen

Konservativa gruppen

Mittengruppen

Vänstersocialistiska gröna gruppen

Konservativa gruppen

Socialdemokratiska gruppen

Vänstersocialistiska gröna gruppen

Socialdemokratiska gruppen

Konservativa gruppen

Socialdemokratiska gruppen

Vänstersocialistiska gröna gruppen

Konservativa gruppen

\section{Nordiska rådets sekretariat/ Nordic Council Secretariat:}

Anne Mette Persdotter

Beate Christine Wang

Britt Bohlin
Kultur- och utbildningsutskottet

Välfärdsutskottet

Rådsdirektör från 1.1.2014 
Hulda Zober Holm

Johan Lindblad

Tryggvi Felixson
Medborgar- och konsumentutskottet

Näringsutskottet

Miljö- och naturresursutskottet

Parlamentens utsända ämbetsmän/ Representative of the parliaments to the EU:

Klaus Andersen

Per Nestande

Tuula Zetterman
Danska folketinget

Norska stortinget

Svenska riksdagen

\section{Delegationssekreterare/ National delegation secretariat:}

$\begin{array}{ll}\text { Bengt Ohlsson } & \text { Sverige } \\ \text { Kjell Myhre-Jensen } & \text { Norge } \\ \text { Mari Herranen } & \text { Finland } \\ \text { Niclas Slotte } & \text { Åland }\end{array}$

Partisekreterare/ General Secretary:

Björg Eva Erlendsdóttir

Kristina Aaltonen

Vänstersocialistiska gröna gruppen

Samuli Virtanen

Socialdemokratiska gruppen

Terhi Tikkala

Nordisk Frihet

Mittengruppen

\section{Övriga personer/ Others:}

Ane Kofod Petersen

Caroline Carpelan

Christine Bogaert

Filippa Orvas Olsson

Jakob Nymann-Lindegren

Jan Widberg

Kenneth Broman

Kjeld B. Olesen

Lars Holte Nielsen

Maya Detiège

Mikael Jansson

Silja Borgarsdottir Sandelin

Tarvo Kungla

Veronica Thörnroos

Vesa Vanhanen
Nordiska ministerrådets sekretariat

Delegationen för Relationer med Vitrysslands sekretariat i Europaparlamentet

Benelux-unionens generalsekretariat

Skåne regionkontor i Bryssel

Danmarks ständiga representation i Bryssel

Östersjökonferensens (BSPC) sekretariat

Nordiska ministerrådets sekretariat

Nord Danmarks regionkontor i Bryssel

Central Danmarks regionkontor i Bryssel

Benelux-unionen

North Sweden regionkontor i Bryssel

Ungdomens Nordiska råd

SINEEA-delegationen i Europaparlamentet

Ålands samarbetsminister

Biträdande enhetschef i Kommissionen 